\title{
Effects of Coronavirus Disease-2019 Pandemic and "New Normal" on the Orthopedic Outpatient Clinic Practice
}

\author{
Koronavirüs Hastalığı-2019 Pandemisi ve "Yeni Normal"in Ortopedi Poliklinik Pratiği \\ Üzerindeki Etkisi \\ izmir University of Economics Medical Park Hospital, Department of Orthopedics and Traumatology izmir Turkey
}

\section{Abstract}

Objective: This study aimed to evaluate the effects of the coronavirus disease-2019 pandemic on the orthopedic outpatient clinic, including an investigation of the number, changes in complaints, and demographics of patients.

Materials and Methods: Data of patients who visited the orthopedic outpatient clinic at our hospital within four periods were evaluated. Period 1 was between March and May 2019, period 2 was between June and August 2019, period 3 was between March and May 2020, and period 4 was between June and August 2020. Data of patients were recorded for each period including age, gender, number, and International Classification of Diseases $10^{\text {th }}$ Revision codes for comparative analysis.

Results: This study included 7,120 patients who were admitted to the orthopedic outpatient clinic within the four periods. The lowest number of patients $(1,119)$ who visited the outpatient clinic was observed in the three months following the pandemic declaration (period $3)$, in March 2020, whereas the highest number $(2,149)$ was observed in the three months following the lifting of restrictions, in June 2020 (period 4). No significant difference was observed in the age between the four periods ( $p=0.945)$. However, a difference was found between the periods for patients aged $\geq 65$ years. Reasons for admission were also different between the periods. In period 3, admissions due to traumatic reasons were statistically higher compared with the other three periods $(p<0.001, p=0.003, p<0.001)$.

Conclusion: It was observed that the number of patients visiting the orthopedic outpatient clinic increased after the restrictions were lifted. Outpatient clinic management must be organized in a way that prevents contamination and preserves efficient outpatient support.

Keywords: COVID-19, pandemic, orthopedics, outpatient clinic, preventive measures

\section{Öz}

Amaç: Bu çalışmanın amacı, koronavirüs hastalığı-2019 pandemisinin ortopedi polikliniği üzerindeki etkilerini değerlendirmek, hasta sayısı, hastaların şikayetlerindeki değişiklikler ve demografik özellikleri araştırmaktır.

Gereç ve Yöntem: Hastanemizde ortopedi polikliniğine başvuran hastaların verileri dört dönem için değerlendirildi. Dönem 1 Mart ve Mayıs 2019 arasında; dönem 2 Haziran ve Ağustos 2019 arasında; dönem 3 Mart ve Mayıs 2020 arasında; ve dönem 4 Haziran ve Ağustos 2020 arasındaydı. Karşılaştırmalı analiz için her dönemde başvuran hastaların yaş, cinsiyet, sayı ve Uluslararası Hastalık Sınıflandırması 10. Revizyon kodları verileri kaydedildi.

Bulgular: Dört dönem içinde ortopedi polikliniğine başvuran toplam 7.120 hasta çalışmaya dahil edildi. En düşük poliklinik başvuru sayısı (1.119), Mart 2020'de pandeminin ilanını takip eden üç ayda (dönem 3) görülürken, en yüksek sayı (2.149), Haziran 2020'de sınırlandırmaların kaldırımasını takip eden üç ayda görüldü (dönem 4). Dört dönem arasında hasta yaşları açısından anlamlı bir fark gözlenmedi ( $p=0,945)$. Bununla birlikte, 65 yaş ve üzeri hastalar için dönemler arasında fark vardı. Polikliniğe başvuru nedenleri de dönemler arasında farklıydı. 3. dönemde travmatik nedenlerle başvurular diğer üç döneme göre istatistiksel olarak daha yüksekti $(p<0,001, p=0,003, p<0,001)$.

Sonuç: Kısıtlamalar kaldıııdıktan sonra ortopedi polikliniğine gelen hasta sayısının arttığı belirlendi. Poliklinik sistemi, kontaminasyonu önleyecek ve hastaların tedavilerinin etkin bir şekilde devam ettirilebileceği şekilde organize edilmelidir.

Anahtar kelimeler: COVID-19, pandemi, ortopedi, poliklinik, koruyucu önlemler

Address for Correspondence/Yazışma Adresi: Çağdaş Biçen Asst. Prof. Dr., İzmir University of Economics Medical Park Hospital, Department of Orthopedics and Traumatology, İzmir, Turkey

Phone: +90 5062735678 E-mail: cagdasbicen@hotmail.com ORCID ID: orcid.org/0000-0002-0711-9376

Received/Geliş Tarihi: 13.01.2021 Accepted/Kabul Tarihi: 22.03.2021

${ }^{\circ}$ Copyright 2021 by the Turkish Osteoporosis Society / Turkish Journal of Osteoporosis published by Galenos Publishing House 


\section{Introduction}

Cases of coronavirus disease-2019 (COVID-19) were first seen in Wuhan, China, in December 2019 (1). The causative agent for COVID-19 is severe acute respiratory syndrome coronavirus 2. On 11 March 2020, the disease was announced as the second pandemic of the $21^{\text {st }}$ century (2). In the treatment of the disease, antiviral agents, antibiotherapies, and supporting treatments are given. Due to high virulence, the control and prevention of contamination and spreading are also important. A great number of precautions have been taken worldwide in order to prevent the spread of the disease. Measures for the public have included the detection of the positive infection using reverse-transcriptase polymerase chain reaction (RT$P(R)$; isolation and quarantine of infected patients; closing of schools and borders; stay at home orders; working from home and social isolation; hand hygiene; and wearing masks (3). There were also precautions taken for the whole health system, patient care, and hospitals. In order to provide efficient support for patients with COVID-19, measurements were taken to ensure a sufficient number of intensive care units and mechanical ventilators. Some hospitals were designated as special facilities for COVID-19, while others were designated as COVID-19-free hospitals. In order to provide sufficient healthcare infrastructure for critical patients and direct sources for the care of COVID-19 patients, it was advised that all elective surgeries should be postponed $(4,5)$. To prevent the spread of the virus during patient care and to protect the healthcare providers, protective barriers were installed and put into use (6). The COVID-19 pandemic impacted orthopedic practices as well as the whole global health system (7). A great number of patients require emergent and non-emergent support in daily orthopedic practice. For the organization of orthopedic surgeries during the pandemic, some guidelines were drawn (8). It was advised that the number of elective surgeries should be reduced or postponed, and they should only be performed in COVID-19-free hospitals (4). It was also determined that there were some surgical procedures and patient groups that should not be delayed (9). Moreover, patients were also categorized into different groups prior to surgery in order to limit the risk of infection (10). Preoperative screening was planned using RT$P C R$, rapid diagnostic tests (RDTs), or computed tomography scans (11). Protective barriers that should be used during surgeries were also defined. It was suggested that patients should be discharged at the earliest possible time, without delay $(12,13)$.

In daily practice, orthopedic surgeons also have to deal with a large number of polyclinic patients. A great number of patients are admitted to orthopedic outpatient clinics with traumatic and non-traumatic complaints. Although measures have been taken for the treatment of hospitalized patients and surgeries during the COVID-19 pandemic, no guidelines are in place for orthopedic outpatient clinics. Moreover, the use of telemedicine has increased in some clinics during the COVID-19 pandemic, including the diagnosis and treatment orthopedic disorders through virtual visits and consultations $(14,15)$. In our clinic, after announcement of the pandemic in March 2020, the number of polyclinic patients decreased dramatically. However, after the restrictions were gradually lifted in June, it was observed that the number of polyclinic patients increased significantly. Herein, it was aimed to investigate the changes in the number, demographic characteristics, and complaints of patients who were admitted to the orthopedic outpatient clinic of our hospital.

\section{Materials and Methods}

This study was conducted retrospectively in our hospital, which is a tertiary care medical center. This research was allowed by the İzmir University of Economics Ethics Committee of the author's institution and was proceeded according to the ethical standards of the 1964 Declaration of Helsinki and later amendments (approval no: B.30.2.IEÜSB.0.05.05-20-100, date: 21.12.2020).

Evaluated were the number, demographic characteristics, and diagnosis of patients admitted to the orthopedic outpatient clinic after the COVID-19 pandemic had been declared. Data were collected from the medical records of the hospital. Recorded were the data of five orthopedic surgeons at the outpatient clinic. In order to compare data, the patients of outpatient clinic were evaluated within four periods. Period 1 was between March and May 2019, period 2 was between June and August 2019, period 3 was between March and May 2020, and period 4 was between June and August 2020. Period 3 was the first three months following the announcement of the pandemic, in March 2020, while period 4 was three months following the lifting of restrictions in June 2020. The data of the patients between these two periods were compared. Furthermore, the data of each period for the same time interval in 2019 were also compared. Data regarding age, gender, number, and International Classification of Diseases $10^{\text {th }}$ Revision (ICD-10) codes of the patients for each period were collected. The gender and age of the patients were investigated. Since it was declared for COVID-19 that the mortality rate was higher and the clinical presentation was heavier in individuals $\geq 65$ years of age, the number of patients at our outpatient clinic who were $<65$ and $\geq 65$ years of age were compared (16). The number of these patients was recorded. Some of the patients visited the outpatient clinic with the same diagnosis more than one time. Within each three-month period, repeated visits with the same diagnosis were counted as one visit. The ICD codes were noted for each period. Repeated visits within each three-month period with the same ICD code for one patient were recorded as one ICD code and duplicated records of the patients were excluded. ICD codes that were recorded more than 20 times in two of the mentioned periods in each year were included in the study. Rare diagnosis with ICD codes that were recorded less than 20 times in the mentioned periods were excluded from the 
analysis. In the case of multiple ICD codes of a patient for the same visit, the related subgroup codes were recorded as one code and different groups of codes were recorded as separate codes. Patient diagnoses on admission to the outpatient clinic were evaluated as traumatic and non-traumatic causes. Moreover, the diagnoses were separated based on their location, as upper extremity, lower extremity, and lower back pathologies.

\section{Statistical Analysis}

The data of the patients were entered into the Microsoft Excel program (Microsoft Corp., Redmond, WA, USA) and for the statistical analysis, IBM SPSS Statistics for Windows 18.0 (IBM Corp., Armonk, NY, USA) was used. To evaluate the numerical data, the mean \pm standard deviation, median (minimum, maximum) were used, while for the categorical data, the number and percentage were used. Distribution of the discrete numerical variables were analyzed using the Kolmogorov-Smirnov test. In cases in which the numerical data were normally distributed, One-Way ANOVA was used for multiple group comparisons, while in cases in which the data were not normally distributed, the Kruskal-Wallis test was used. Gender, age, etiology of the complaints, and location of the complaints were recorded for each period using cross tables. Differences between the groups were compared using the chi-square. Bonferroni correction was applied to define the groups that had statistical differences. $\mathrm{P}<0.05$ was considered statistically significant.

\section{Results}

A total of 7,120 patients, comprising 3,542 males (49.7\%) and 3,578 females (50.3\%), were admitted by five orthopedic surgeons at our outpatient clinic, within the four periods. The average of age of the patients was $41.6 \pm 18.3$ years, and 6,209 patients $(87.2 \%)$ were $<65$ years of age, while 911 patients $(12.8 \%)$ were $\geq 65$ years of age (Figure 1$)$. In period 1 , a total of 2,078 patients $(29.2 \%$ ) visited the orthopedic outpatient clinic at our hospital and in period 2, this number was 1,774 patients $(24.9 \%)$. In period 3, the number of patients who visited our outpatient clinic was 1,119 (15.7\%) (0.54 times the total number of patients in period 1). In period 4 , the number of patients admitted was 2,149 (30.2\%), which was the highest number within the four periods (1.9 times that in period 3). In period 1, 342 of the 2,078 patients (16.5\%), in the period 2385 of the 1,774 patients $(21.7 \%)$, in period 3 226 of the 1,119 patients (20.2\%), and in period 4507 of the 2,249 patients $(23.5 \%)$ had visited the orthopedic outpatient clinic of our hospital for the first time. Regarding the ICD codes on admission, the diagnoses were divided into groups as traumatic and non-traumatic disorders. Overall, $52.1 \%$ of the patients were admitted with non-traumatic disorders, while $47.6 \%$ were admitted with traumatic complaints, and $0.3 \%$ had both traumatic and non-traumatic complaints on admission. Also investigated were the ICD codes with regards to the locations of the complaints. It was determined that
$57.5 \%$ of the patients were admitted with lower extremity complaints, $25.6 \%$ were admitted with upper extremity complaints, and $11.3 \%$ had vertebral pathologies. Moreover, $2.1 \%$ of the patients had complaints in both extremities, $2.1 \%$ had complaints in the lower extremity and vertebra, $1.1 \%$ had complaints in the upper extremity and vertebra, and $0.2 \%$ had complaints in all three regions (Table 1).

The demographic characteristics and complaints of the patients were also compared between the four periods in order to evaluate the effects of the pandemic on the orthopedic outpatient clinic. There were no statistically significant differences with regards to age between the four periods ( $p=0.945)$. However, there was a difference between the periods with regards patients $\geq 65$ years of age. In periods 3 and 4 (after the declaration of pandemic), a higher number of patients $<65$ years of age were admitted when compared with period $1(p=0.001, p=0.003)$. A difference was also observed between the periods with regard to gender. In periods 1, 2, and 4, the majority of the patients that had visited the outpatient clinic were females and there was no statistically significant difference between these three periods. In period 3, following the declaration of the pandemic, a statistically significantly higher number of male patients seemed to visit the outpatient clinic $(p=0.003)$. The etiologies of admission were also different between the time periods. In period 3, there was a statistically higher number of admissions due traumatic reasons when compared with the other three time periods $(p<0.001$, $p=0.003, p<0.001$ ). Locations of the complaints also seemed to vary among the time periods. Lower extremity disorders were higher in periods 1, 2, and 4 when compared with period 3 $(p<0.001, p<0.001, p=0.002)$. Upper extremity complaints were higher in periods 1 and 2 in comparison with period $3(p<0.001$, $p<0.001)$. Upper extremity complaints on admission were lower in period 2 when compared with period $4(p<0.001)$. Vertebral disorders were found to be similar between the 4 periods $(p=0.30)$ (Figure 2-4).



Figure 1. Distribution of ages of the patients those visited orthopedic outpatient clinic 


\section{Discussion}

In March 2020, COVID-19 was announced as a pandemic and thereafter, there were changes in daily practice in almost every area. Changes were also observed at the orthopedic outpatient clinic of our hospital. Herein, it was aimed to evaluate the effects of the COVID-19 pandemic on orthopedic outpatient practice. Just after the announcement of the pandemic, many restrictions were applied all over the world, as well as in Turkey. In the three months following this, the number of patients admitted to our outpatient clinic decreased dramatically. As the restrictions began to be lifted on June 2020, with the "new normal", it was observed that the number of patients who visited our outpatient clinic increased again. When the number of outpatient visits during the three months following the announcement of the pandemic were compared with the same time interval of the previous year, it was seen that between March and May 2019 (period 1), 2,078 patients were admitted to the outpatient clinic, and this number decreased to 1,119 between March and May 2020 (period 3). The number of patients increased to 2149 in

Number of admissions

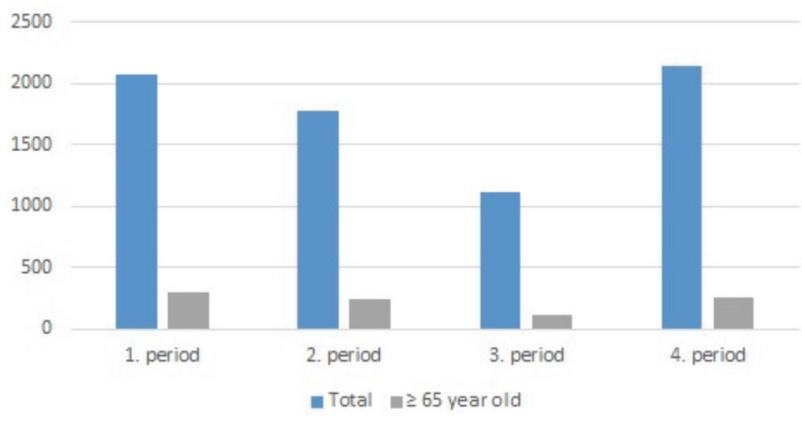

Figure 2. Graphic showing total number of patients and patients $\geq 65$ years old those were admitted in the orthopedic outpatient clinic in four periods the three months following the lifting restrictions (period 4). It was observed that the highest number of patients visited the outpatient clinic after the restrictions had been lifted, in period 4, when compared with period 3, and with same period of the previous year (period 2). Although there were limitations in many areas, the need for medical support was observed to increase in period 4 and it was not possible to

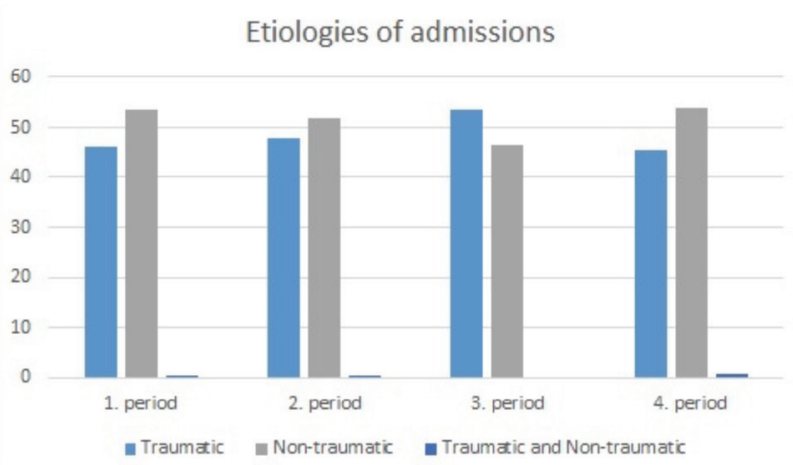

Figure 3. Graphic showing etiologies of the admissions in four periods

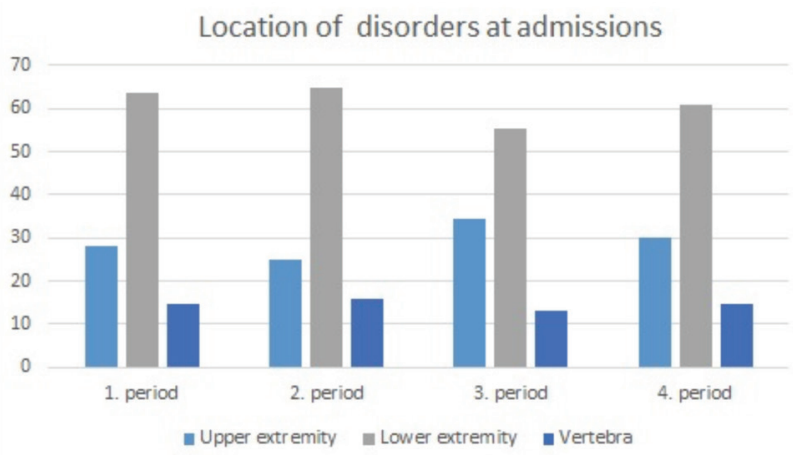

Figure 4. Graphic showing location of the complaints at the admissions in four periods

\section{Table 1. Demographics of the patients and admissions in four periods}

\begin{tabular}{|l|l|l|l|l|}
\hline Periods & Period 1 & Period 2 & Period 3 & Period 4 \\
\hline Number of patients & 2,078 & 1,774 & 1,119 & 2,149 \\
\hline Gender (female/male) & $1,064 / 1,014$ & $914 / 860$ & $505 / 614$ & $1,095 / 1,054$ \\
\hline Age (mean) & $41.75 \pm 18.95$ & $41.92 \pm 18.54$ & $41.19 \pm 17.09$ & $41.39 \pm 17.96$ \\
\hline Percentage of patients $\geq 65$ years old & 14.5 & 13.7 & 10.5 & 11.5 \\
\hline Etilogy (percentage) & \multicolumn{5}{|l|}{} \\
\hline Traumatic & 46.2 & 47.9 & 53.6 & 45.5 \\
\hline Non-traumatic & 53.6 & 52.0 & 46.4 & 53.9 \\
\hline Traumatic and non-traumatic & 0.20 & 0.17 & 0 & 0.6 \\
\hline Location (percentage) & \multicolumn{5}{|l}{} \\
\hline Upper extremity & 27.9 & 25 & 34.4 & 30.2 \\
\hline Lower extremity & 63.6 & 64.9 & 55.3 & 14.8 \\
\hline Vertebra & 14.6 & 15.8 & 13.2 & \\
\hline Period 1: March-May 2019, period 2: June-August 2019, period 3: March-May 2020, period 4: June-August 2020 & \\
\hline
\end{tabular}


limit outpatient visits, as patients demanded uninterrupted outpatient clinic support. It was believed that increased visits for orthopedic outpatient clinics might be risky for health care providers. Rates of infection caused by COVID-19 have been rising recently and the second wave was observed to have begun in some countries (17). Algorithms were planned for health management for the future $(18,19)$. In order to avoid contamination in crowded outpatient clinics, temperature checks can be performed prior to the visits at triage points in the hospitals. Masks should be compulsory, not only for health care providers, but also for the patients. Gloves should be used as a supporting barrier in examinations. RDTs have been used wide and these tests can be performed before examinations $(20,21)$. It is our belief that orthopedic surgeons are also at increased risk during this period due to the increased number of patients, and outpatient clinic management has to be taken to consideration now, as well in the future. Telemedicine has been used in some clinics and defined as a good option of diagnosis and treatment (22). In our institute, telemedicine has not been the preferred option by the patients during the pandemic and to the best of our knowledge, it has not been accepted in the general population as an alternative to outpatient clinic support.

In this study it was also aimed to investigated the effects of the pandemic on our orthopedic outpatient clinic. It was observed that patients $\geq 65$ years of age avoided visiting the outpatient clinic at the beginning of the pandemic. However, in period 4, it was observed that the number of patients $\geq 65$ years of age reached a level similar to that in period 2 . Moreover, $80 \%$ of the patients who had been hospitalized for COVID-19 infection were $>65$ years of age and in this population, the risk of mortality was observed to be 23-fold higher (23). It was advised that age had to be taken into consideration while planning preventive measurements in recent studies $(24,25)$. As patients $\geq 65$ years of age form a significant portion of the orthopedic outpatient clinic, preventive measurements should be planned regarding this age group.

The etiologies of admission of the patients were recorded by our outpatient clinic. It was seen that non-traumatic cases were higher than traumatic cases. Admissions caused by trauma were higher following the declaration of the pandemic, and it seemed that patients that opted for elective support visited our outpatient clinic less during that period (period 3). However, since June 2020, it was observed that admissions due to nontraumatic disorders have begun to increase. In the study of de Caro et al. (11), a multilevel gate approach was suggested for orthopedic surgeries during the COVID-19 pandemic. A multilevel approach can also be planned for outpatient clinics, in order to provide safer outpatient support.

Some changes were also observed in the admissions regarding the location of the complaints. A large number of employees have been working from home since the beginning of the COVID-19 pandemic. It was expected that vertebral disorders, such as hernias and back pain, which are caused by bad posture, would be among the major causes of admission. However, no difference was observed during this period with regards to the rate of vertebral disorders.

This study had several limitations. The retrospective design of the study was a major limitation. The study showed the changes at only one institution. Some of the data in the study were collected using ICD-10 codes. This was another limitation in the study. Although the ICD coding system is accepted worldwide, it may not always reflect the direct complaints of the patients.

\section{Conclusion}

It was our belief that patients avoided visiting orthopedic outpatient clinics as the result of their fear of contamination. After the cases were limited as a result of the restrictions, the number of visits increased. It seemed that the interruption of orthopedic outpatient services, resulted in the growth of the number of patients who required orthopedic support. As the second wave of the pandemic is underway, this circular reasoning may result in a large number of patients necessitating support. An increased number of patients in outpatient clinics would increase the risk of infection with COVID-19. For these reasons, preventive measurements should be taken and the management of orthopedic outpatient clinics has to be planned for sustainable medical support during the COVID-19 pandemic.

\section{Ethics}

Ethics Committee Approval: This research was allowed by the İmir University of Economics Ethics Committee of the author's institution and was proceeded according to the ethical standards of the 1964 Declaration of Helsinki and later amendments (approval no: B.30.2. IEÜSB.0.05.05-20-100, date: 21.12.2020).

Informed Consent: Retrospective study.

Peer-review: Externally and internally peer-reviewed.

\section{Authorship Contributions}

Surgical and Medical Practices: Ç.B., M.A.T., Concept: Ç.B., M.A.T., Design: Ç.B., M.A.T., Data Collection or Processing: C..B., Analysis or Interpretation: Ç.B., M.A.T., Literature Search: Ç.B., Writing: Ç.B.

Conflict of Interest: No conflict of interest was declared by the authors.

Financial Disclosure: The authors declared that this study has received no financial support.

\section{References}

1. D'Ambrosi R. Orthopedics and COVID-19: Scientific Publications Rush. Indian J Orthop 2020; 54:1-7.

2. Rothan HA, Byrareddy SN. The epidemiology and pathogenesis of coronavirus disease (COVID-19) outbreak. J Autoimmun 2020;109:102433.

3. Cheng VC, Wong SC, Chuang VW, So SY, Chen JH, Sridhar S, et al. The role of community-wide wearing of face mask for control of coronavirus disease 2019 (COVID-19) epidemic due to SARSCoV-2. J Infect 2020;81:107-14. 
4. Mouton C, Hirschmann MT, Ollivier M, Seil R, Menetrey J. COVID-19 - ESSKA guidelines and recommendations for resuming elective surgery. J Exp Orthop 2020;7:2.

5. American College of Surgeons (ACS). 2020 COVID-19 update: guidance for triage of non-emergent surgical procedures. https:// www.facs.org/covid-19/clinical-guidance/triage Accessed 13 Mar 2020.

6. Hirschmann MT, Hart A, Henckel J, Sadoghi P, Seil R, Mouton C. COVID-19 coronavirus: recommended personal protective equipment for the orthopaedic and trauma surgeon. Knee Surg Sports Traumatol Arthrosc 2020;28:1690-8.

7. Jain VK, Vaishya R. COVID-19 and orthopaedic surgeons: the Indian scenario. Trop Doct 2020;50:108-10.

8. Sarac NJ, Sarac BA, Schoenbrunner AR, Janis JE, Harrison RK, Phieffer LS, et al. A Review of State Guidelines for Elective Orthopaedic Procedures During the COVID-19 Outbreak. J Bone Joint Surg Am 2020;102:942-5

9. DePhillipo NN, Larson CM, O'Neill OR, LaPrade RF. Guidelines for Ambulatory Surgery Centers for the Care of Surgically Necessary/ Time-Sensitive Orthopaedic Cases During the COVID-19 Pandemic. J Bone Joint Surg Am 2020;102:933-6.

10. Fineberg HV. Ten Weeks to Crush the Curve. N Engl J Med 2020;382:e37.

11. de Caro F, Hirschmann TM, Verdonk P. Returning to orthopaedic business as usual after COVID-19: strategies and options. Knee Surg Sports Traumatol Arthrosc 2020;28:1699-704.

12. Chang Liang Z, Wang W, Murphy D, Po Hui JH. Novel Coronavirus and Orthopaedic Surgery: Early Experiences from Singapore. J Bone Joint Surg Am 2020;102:745-9.

13. Jansen JA, Kruidenier J, Spek B, Snoeker BAM. A cost-effectiveness analysis after implementation of a fast-track protocol for total knee arthroplasty. Knee 2020;27:451-8.

14. Tanaka MJ, Oh LS, Martin SD, Berkson EM. Telemedicine in the Era of COVID-19: The Virtual Orthopaedic Examination. J Bone Joint Surg Am 2020;102:e57.

15. Makhni MC, Riew GJ, Sumathipala MG. Telemedicine in Orthopaedic Surgery: Challenges and Opportunities. J Bone Joint Surg Am 2020;102:1109-15.
16. Vestergaard LS, Nielsen J, Richter L, Schmid D, Bustos N, Braeye $\mathrm{T}$, et al. Excess all-cause mortality during the COVID-19 pandemic in Europe - preliminary pooled estimates from the EuroMOMO network, March to April 2020. Euro Surveill 2020;25:2001214.

17. Cacciapaglia G, Cot C, Sannino F. Second wave COVID-19 pandemics in Europe: a temporal playbook. Sci Rep 2020;10:15514.

18. Waydhas C, Hosbach I, Bockelmann-Jung S, Hamsen U, Kaufmann P, Knop-Hammad V, et al. [Algorithm for flexible decision-making in the intra-hospital management of patients with the changing requirements of the SARS-CoV-2 pandemic]. Notf Rett Med 2020 Jul 7:1-8. German.

19. Lai JW, Cheong KH. Superposition of COVID-19 waves, anticipating a sustained wave, and lessons for the future. Bioessays 2020;42:e2000178.

20. Andrey DO, Cohen P, Meyer B, Torriani G, Yerly S, Mazza L, et al. Diagnostic accuracy of Augurix COVID-19 IgG serology rapid test. Eur J Clin Invest 2020;50:e13357.

21. Porte L, Legarraga P, Vollrath V, Aguilera X, Munita JM, Araos R, et al. Evaluation of a novel antigen-based rapid detection test for the diagnosis of SARS-CoV-2 in respiratory samples. Int J Infect Dis 2020;99:328-33.

22. Tanaka MJ, Oh LS, Martin SD, Berkson EM. Telemedicine in the Era of COVID-19: The Virtual Orthopaedic Examination. J Bone Joint Surg Am 2020;102:e57.

23. Mueller AL, McNamara MS, Sinclair DA. Why does COVID-19 disproportionately affect older people? Aging (Albany NY) 2020;12:9959-81.

24. Kang SJ, Jung SI. Age-Related Morbidity and Mortality among Patients with COVID-19. Infect Chemother 2020;52:154-64

25. Romero Starke K, Petereit-Haack G, Schubert M, Kämpf $D$, Schliebner A, Hegewald J, et al. The Age-Related Risk of Severe Outcomes Due to COVID-19 Infection: A Rapid Review, MetaAnalysis, and Meta-Regression. Int J Environ Res Public Health 2020;17:5974. 